\title{
Bactericidal properties of disinfectant DZPT-2 against enterobacteria
}

\author{
A. Palii, \\ doctor of veterinary science \\ National scientific center «Institute of experimental and clinical veterinary medicine»
}

The purpose. To study bactericidal properties against enterobacteria of new sanitizing specimen DZPT-2. Methods. They used test-culture of enterobacterium Salmonella spp. At determination of bactericidal properties disinfectant the used suspension method of probes, as well as test-objects. Results. Specimen DZPT-2 has bacteriostatic and bactericidal properties against representatives of stem Salmonella spp. It depends on its density and exposure. Conclusions. Sanitizing specimen DZPT-2 manifests bactericidal properties against causal organisms of salmonellosises in density of $0,5-1 \%$ as to working matter at exposure of 3 hours.

Key words: sanitizing specimen, DZPT-2, test-crop, enterobacterium, density, exposure, bactericidal action.

Formulation of the problem. Today the increasing amount of work in search of a new generation of disinfectants, forms and methods of their application. The development of research in these areas need further research on improving the selection, testing and evaluation of new chemical disinfectants, studying and testing new drugs in laboratory and industrial conditions, their implementation in practice veterinary disinfection. In addition, searching and testing new products for disinfection of objects of veterinary supervision, particularly relevant against the backdrop of environmental environmental changes and threatening epizootic situation.

Analysis of recent research and publications. Disinfection measures is an important practical aspects in liquidation and nonspecific prevention of many infectious diseases in humans and animals and are essential for the successful operation of a number of economic activities. In the structure of total losses in livestock occupy a significant portion of underperformance veterinary and sanitary measures, including disinfection [1].

Despite that finding and studying new disinfectants engaged sufficiently large number of scientists and veterinary practice currently lacks highly efficient, cost-effective drugs suitable for livestock sanitation facilities [2, 3].

In order to reduce the deficit sanitary facilities, improving the quality of manufactured products and improving the environment requires the development of effective drugs, mainly on the basis of compositional, which contain several active ingredients. This popular domestic boilers, as they are not inferior in quality to foreign analogues, but are much more economical [4,5]. When choosing a disinfectant and detergent in the first place should be its effectiveness, and then the price [6].

Microbial cultures are characterized by heterogeneity in the degree of sensitivity to disinfectants. There has dependence sensitivity to disinfectants of genus and species of microorganism. Among the fate of staphylococci sensitivity is about $85 \%$. Incomplete recording sensitivity among members of the family Enterobacteriaceae. She manifested only in isolated cultures Proteus and Salmonella, and was slightly higher in the intestinal bacillus [7].

It should be noted that constantly changes the background as a result of microbial adaptation to disinfectants commonly used in animal husbandry. Increasingly reveal strains of microorganisms resistant to conventional disinfectants, prevalent microorganisms not sensitive to negative factors. Increasingly cause various pathological conditions is not certain pathogens and their associations. [8] For actions subbactericidal concentrations of antimicrobial agent may not affect the viability of microorganisms but causes no cultivate state [9]. 
Given the above, scientists NSC "IECVM" the new disinfectants that are offered for use in veterinary medicine practice [10].

The purpose of research - to examine the antibacterial properties to Enterobacteriaceae new complex disinfectants "DZPT-2".

Materials and methods of research. In experiments used disinfectants "DZPT-2" (registration certificate number AB-02329-03-11 of 02.03.2017), which is developing innovative import-substituting National Scientific Center "IECVM."

During the performance used test culture Enterobacteriaceae: Salmonella Dublin (strain 41), Salmonella Enteritidis (strain M), Salmonella Heidelberg (strain E 19), Salmonella Infantis (strain 51), Salmonella Typhimurium (strain B), Salmonella Typhisuis (strain 399), Salmonella Virchow (strain 42). Cultures were incubated at a temperature of $37,5 \pm 0,5^{\circ} \mathrm{C}$ in MPB and MPA.

In determining bactericidal disinfectant properties primary step was to study its performance suspension using research methods. For this test bacterial cultures were sown on nutrient media slanted, which was incubated at a temperature of $37,5 \pm 0,5^{\circ} \mathrm{C}$. Purity control growth cultures done by microscoping smears stained by Gram. Net daily test crops washed away from the surface of culture media sterile saline.

Investigated breeding disinfectants poured into sterile bacteriological test tubes to $5,0 \mathrm{~cm}^{3}$. Test tubes culture contributed to the preparation of the necessary quantity in such a way that the final concentration was 2 billion microorganisms. CFU $/ \mathrm{cm}^{3}$ (according to standard optical turbidity). As used similar control dilution test cultures in sterile saline. For each dilution of the drug at different exposures used 3 tubes. After maintaining the desired exposure of each tube made hanging on a Petri dish with nutrient medium (in a volume of $0,5 \mathrm{~cm}^{3}$ ). Hung incubated at a temperature of $37,5 \pm 0,5{ }^{\circ} \mathrm{C}$ for $24-48$ hours. Control growth was performed visually and by microscoping smears.

After studying the bactericidal properties of drugs suspension was carried out by the second phase of studies using test objects and subject to biological stress (bovine serum inactivated). As test objects used lawn, wood, tile, metal, glass. Prior research test facilities were sterilized by autoclaving by mode: $132{ }^{\circ} \mathrm{C} ., 2$ atm., $60 \mathrm{~min}$. Sterile test facilities roztashovuvaly sterile cuvettes and deposited on the surface of the test suspension culture and inactivated bovine serum at the rate $-1 \mathrm{~cm}^{3}$ standardized test culture serum and 0,5 $\mathrm{cm}^{3}$ per $100 \mathrm{~cm}^{2}$ area of the test object. Then the surface contaminated test sites applied disinfectant working solution in the studied concentrations of disinfectant rate of $5 \mathrm{~cm}^{3} 100 \mathrm{~cm}^{2}$ square test object. In the control test items in the same volumes of sterile saline was applied.

Sterile swab moistened with saline wipes made from the surface of the test object. Swabs were washed for 15 minutes in $10 \mathrm{~cm}^{3}$ of sterile saline solution, liquid centrifuged at $1500 \mathrm{rev} / \mathrm{min}$ for 15 minutes. The precipitate formed was resuspended with sterile saline and plated on nutrient media (in volume of $0,5 \mathrm{~cm}^{3}$ ). Controlling the growth of crops carried out visually and by microscoping strokes at 24 and 48 hours.

The results of research. The primary step was to determine the bactericidal properties of disinfection preparation on suspension cultures of microorganisms by research. Disinfectants "DZPT 2" was investigated at a concentration of 0,5 and $1,0 \%$ for the active substance (AS) for the exposure action 30 minutes; $1 ; 3 ; 5$; 24 hours. The studies presented in Table 1.

The results of the research study of bactericidal action of the drug "DZPT 2" (Table. 1) indicate that it is at a concentration of $0,5 \%$ by AS exposure for 30 minutes has bactericidal effect on test cultures of microorganisms. With increasing exposure to 1 hour microorganisms studied partially restored their reproductive properties. Effects of the drug at a concentration of $0,5 \%$ by AS exposure for $3-24$ hours completely destroying enterobacteria.

\section{Bactericidal action of the drug "DZPT-2" solution, $M \pm m, n=3$}

\begin{tabular}{|c|c|c|c|c|c|c|}
\hline \multirow{2}{*}{ Test-cultures } & \multicolumn{5}{|c|}{ Exposure } & \multirow{2}{*}{$\begin{array}{l}\text { Contr } \\
\text { ol }\end{array}$} \\
\hline & $30 \mathrm{~min}$ & 1 hours & 3 hours & 5 hours & 24 hours & \\
\hline \multicolumn{7}{|c|}{ concentration $0,5 \%$ by AS } \\
\hline S. Dublin & DG & $10,2 \pm 0,66$ & - & - & - & DG \\
\hline
\end{tabular}




\begin{tabular}{|l|l|l|l|l|l|l|}
\hline S. Enteritidis & DG & $9,3 \pm 0,44$ & - & - & - & DG \\
\hline S. Heidelberg & DG & $9,0 \pm 0,66$ & - & - & - & DG \\
\hline S. Infantis & DG & $10,3 \pm 0,11$ & - & - & - & DG \\
\hline S. Typhimurium & DG & $10,0 \pm 0,66$ & - & - & - & DG \\
\hline S. Typhisuis & DG & $10,2 \pm 0,37$ & - & - & - & DG \\
\hline S. Virchow & DG & $11,3 \pm 0,17$ & - & - & - & DG \\
\hline concentration 1,0 \% by AS & $(1,20 \pm 0,05) \times 10^{2}$ & - & - & - & - & DG \\
\hline S. Dublin & $(1,15 \pm 0,03) \times 10^{2}$ & - & - & - & - & DG \\
\hline S. Enteritidis & $(1,20 \pm 0,04) \times 10^{2}$ & - & - & - & - & DG \\
\hline S. Heidelberg & $(1,16 \pm 0,02) \times 10^{2}$ & - & - & - & - & DG \\
\hline S. Infantis & $(1,22 \pm 0,02) \times 10^{2}$ & - & - & - & - & DG \\
\hline S. Typhimurium & $(1,21 \pm 0,03) \times 10^{2}$ & - & - & - & - & DG \\
\hline S. Typhisuis & $(1,17 \pm 0,04) \times 10^{2}$ & - & - & - & - & DG \\
\hline S. Virchow & - & - & - & - & - & - \\
\hline
\end{tabular}

Notes: "-" - no growth; "DG" - drain growth.

At concentrations of $1,0 \%$ by AS exposure for 30 minutes drug "DZPT-2" reveals bacteriostatic action research on test crops, reducing their reproductive properties. For one exposure - 24 hours "DZPT 2" at a concentration of $1,0 \%$ by AS for all members inactivate Salmonella spp.

After studying the bactericidal properties of the drug "DZPT-2" suspension method, studies with different test objects (lawn, wood, tile, metal, glass) and taking into account the biological load (bovine serum inactivated).

Given the fact that in experiments on nutrient media was found no bactericidal action in "DZPT-2" exhibition for 30 minutes in experiments at test sites used exposure from 1 to 24 hours results of these studies are presented in tables 2 and 3.

2. Bactericidal action "DZPT-2" ( $0,5 \%$ by AS) of the test sites, $M \pm m, n=3$

\begin{tabular}{|c|c|c|c|c|c|c|c|c|c|c|}
\hline \multirow{3}{*}{$\begin{array}{l}\text { Test- } \\
\text { cultures }\end{array}$} & \multicolumn{2}{|l|}{ lawn } & \multicolumn{2}{|l|}{ wood } & \multicolumn{2}{|l|}{ tile } & \multicolumn{2}{|l|}{ metal } & \multicolumn{2}{|l|}{ glass } \\
\hline & \multicolumn{10}{|c|}{ Exposure, hours } \\
\hline & 1 & 3 & 1 & 3 & 1 & 3 & 1 & 3 & 1 & 3 \\
\hline S. Dublin & $\begin{array}{l}(2,27 \pm \\
0,03) \times 10^{2}\end{array}$ & - & $\begin{array}{l}(2,24 \pm \\
0,03) \times 10^{2}\end{array}$ & - & $\begin{array}{l}12,4 \pm \\
0,3\end{array}$ & - & $\begin{array}{l}12,4 \pm \\
0,3\end{array}$ & - & $\begin{array}{l}13,1 \pm \\
0,3\end{array}$ & - \\
\hline $\begin{array}{l}\text { S. } \\
\text { Enteritidis }\end{array}$ & $\begin{array}{l}(2,23 \pm \\
0,04) \times 10^{2}\end{array}$ & - & $\begin{array}{l}(2,00 \pm \\
0,05) \times 10^{2}\end{array}$ & - & $\begin{array}{l}15,4 \pm \\
0,3\end{array}$ & - & $\begin{array}{l}15,4 \pm \\
0,3\end{array}$ & - & $\begin{array}{l}15,5 \pm \\
0,3\end{array}$ & - \\
\hline $\begin{array}{l}\text { S. } \\
\text { Heidelberg }\end{array}$ & $\begin{array}{l}(2,46 \pm \\
0,06) \times 10^{2}\end{array}$ & - & $\begin{array}{l}(2,40 \pm \\
0,06) \times 10^{2}\end{array}$ & - & $\begin{array}{l}25,2 \pm \\
0,2\end{array}$ & - & $\begin{array}{l}20,2 \pm \\
0,3\end{array}$ & - & $\begin{array}{l}24,3 \pm \\
0,2\end{array}$ & - \\
\hline $\begin{array}{l}\text { S. } \\
\text { Infantis }\end{array}$ & $\begin{array}{l}(2,45 \pm \\
0,05) \times 10^{2}\end{array}$ & - & $\begin{array}{l}(2,30 \pm \\
0,05) \times 10^{2}\end{array}$ & - & $\begin{array}{l}24,3 \pm \\
0,4\end{array}$ & - & $\begin{array}{l}22,3 \pm \\
0,5\end{array}$ & - & $\begin{array}{l}22,3 \pm \\
0,4\end{array}$ & - \\
\hline $\begin{array}{l}\text { S. Typhi- } \\
\text { murium }\end{array}$ & $\begin{array}{l}(2,25 \pm \\
0,06) \times 10^{2}\end{array}$ & - & $\begin{array}{l}(2,12 \pm \\
0,06) \times 10^{2}\end{array}$ & - & $\begin{array}{l}18,3 \pm \\
0,5\end{array}$ & - & $\begin{array}{l}18,3 \pm \\
0,6\end{array}$ & - & $\begin{array}{l}17,3 \pm \\
0,5\end{array}$ & - \\
\hline S. Typhisuis & $\begin{array}{l}(2,49 \pm \\
0,07) \times 10^{2}\end{array}$ & - & $\begin{array}{l}(2,33 \pm \\
0,06) \times 10^{2}\end{array}$ & - & $\begin{array}{l}22,3 \pm \\
0,3\end{array}$ & - & $\begin{array}{l}19,3 \pm \\
0,3\end{array}$ & - & $\begin{array}{l}21,2 \pm \\
0,3\end{array}$ & - \\
\hline $\begin{array}{l}\text { S. } \\
\text { Virchow }\end{array}$ & $\begin{array}{l}(2,22 \pm \\
0,07) \times 10^{2}\end{array}$ & - & $\begin{array}{l}(2,00 \pm \\
0,07) \times 10^{2}\end{array}$ & - & $\begin{array}{l}20,1 \pm \\
0,4\end{array}$ & - & $\begin{array}{l}19,9 \pm \\
0,4\end{array}$ & - & $\begin{array}{l}21,1 \pm \\
0,4\end{array}$ & - \\
\hline
\end{tabular}

Notes: "-" - no growth. 
The results of studies using the drug "DZPT-2" at a concentration of $0,5 \%$ by AS (Table. 2) revealed that he finds antibacterial properties, since exposure 3 hours, then, as the exhibition 1:00 dezzasib effect on microorganisms bacteriostatic and inhibits the reproductive properties of test cultures.

\section{Bactericidal action "DZPT-2" (1,0\% by AS) of the test sites, $M \pm m, n=3$}

\begin{tabular}{|c|c|c|c|c|c|c|c|c|c|c|}
\hline \multirow{3}{*}{ Test-cultures } & \multicolumn{2}{|c|}{ lawn } & \multicolumn{2}{|c|}{ wood } & \multicolumn{2}{|c|}{ tile } & \multicolumn{2}{|c|}{ metal } & \multicolumn{2}{|c|}{ glass } \\
\hline & \multicolumn{10}{|c|}{ Exposure, hours } \\
\hline & 1 & 3 & 1 & 3 & 1 & 3 & 1 & 3 & 1 & 3 \\
\hline S. Dublin & $\begin{array}{l}6,9 \pm \\
0,2\end{array}$ & - & $\begin{array}{l}6,8 \pm 0 \\
, 3\end{array}$ & - & - & - & - & - & - & - \\
\hline S. Enteritidis & $\begin{array}{l}7,0 \pm \\
0,3\end{array}$ & - & $\begin{array}{l}6,8 \pm 0 \\
, 1\end{array}$ & - & - & - & - & - & - & - \\
\hline S. Heidelberg & $\begin{array}{l}6,9 \pm \\
0,5\end{array}$ & - & $\begin{array}{l}6,6 \pm 0 \\
, 2\end{array}$ & - & - & - & - & - & - & - \\
\hline S. Infantis & $\begin{array}{l}5,8 \pm \\
0,1\end{array}$ & - & $\begin{array}{l}5,2 \pm 0 \\
, 3\end{array}$ & - & - & - & - & - & - & - \\
\hline S. Typhimurium & $\begin{array}{l}6,6 \pm \\
0,3\end{array}$ & - & $\begin{array}{l}5,9 \pm 0 \\
, 5\end{array}$ & - & - & - & - & - & - & - \\
\hline S. Typhisuis & $\begin{array}{l}8,4 \pm \\
0,6\end{array}$ & - & $\begin{array}{l}8,0 \pm 0 \\
, 1\end{array}$ & - & - & - & - & - & - & - \\
\hline S. Virchow & $\begin{array}{l}7,1 \pm \\
0,2\end{array}$ & - & $\begin{array}{l}6,8 \pm 0 \\
, 5\end{array}$ & - & - & - & - & - & - & - \\
\hline
\end{tabular}

Notes: "-" - no growth.

The results presented in Table 3 revealed that the application of a test object tiles, glass, metal preparation "DZPT-2" at a concentration of $1,0 \%$ by AS for exposure characterized 1:00 bactericidal activity against all studied microorganisms.

At the same time in experiments with wood and lawn drug acts only subbactericidal. Since 3:00 exposition drug "DZPT-2" fully disinfects all contaminated test sites.

The obtained results show that disinfectants "DZPT-2" has antibacterial properties on the genus Enterobacteriaceae.

\section{Conclusions}

Studied the antibacterial properties of new disinfectants "DZPT-2" on the genus Salmonella spp.

Disinfectants "DZPT-2" exhibits antibacterial properties to pathogens salmonella at a concentration of 0,5 $-1,0 \%$ by AS exposure steps 3 hours.

The prospect of further research is to study the spectrum of antimicrobial action of the drug on the causative agents of especially dangerous infectious animal diseases.

\section{Bibliography}

1. Oshhepkov V.G. Jepizooticheskoe blagopoluchie po zooantroponozam - vazhnyj rezerv povyshenija rentabel'nosti zhivotnovodstva [Tekst] / V.G. Oshhepkov // Veterinarija i kormlenie. - 2009. - № 4. - S. 23-24.

2. Palij A.P. Innovacijni tehnologiï ta tehnichni sistemi u molochnomu skotarstvi. Naukovo-navchal'nij posibnik [Tekst] / A.P. Palij, A.P. Palij, O.A. Naumenko. - H.: «Mis'kdruk». - 2015. - 324 s.

3. Palij A.P. Sravnitel'noe izuchenie baktericidnyh svojstv novyh dezinfektantov [Tekst] / A. P. Palij, A. I. Zavgorodnij // Izvestija nac. agrar. un-ta Armenii. - 2013. - № 2. - S. 39-41.

4. Palij A.P. Porivnjal'ne vyznachennja bakterycydnyh vlastyvostej shhodo mikobakterij dezinfekcijnyh preparativ vitchyznjanogo vyrobnyctva [Tekst] // Veterynarna medycyna Ukrai'ny. - 2006. - № 2. - S. 40-42. 
5. Naukovi ta praktychni aspekty dezinfekcii' u veterynarnij medycyni [Tekst] / A.I. Zavgorodnij, B.T. Stegnij, A.P. Palij [ta in.]. - H. : FOP Brovin O.V., 2013. - $222 \mathrm{~s}$.

6. Best M. Efficacies of selected disinfectants against Mycobacterium tuberculosis [Text] / M. Best [et al.] // J. Clin. Microbiol. - 1990. - Vol. 28, № 10. - P. 2234-2239.

7. Mefod'ev V.V. Ocenka vlijanija nekotoryh dezinfektantov na formirovanie atipichnyh shtammov mikroorganizmov [Tekst] / V.V. Mefod'ev, O.P. Markova [i dr.] // Dezinfekcionnoe delo. - 2010. - № 4. - S. 42-44.

8. Kononenko A.B. Formirovanie ustojchivosti mikroorganizmov $\mathrm{k}$ vozdejstviju dezinficirujushhih preparatov [Tekst] / A.B. Kononenko, D.A. Bannikov, S.V. Britova [i dr.] // RZh «Probl. vet. sanitarii, gigieny i jekologii». - 2015. - № 3 (15). - S. 46-52.

9. Lee S. DNA hybridization to compare species compositions of natural bacterioplankton assem - blages [Text] / S. Lee, J.A. Fuhrman // Appl. Environ. Microbiol. - 1990. - Vol. 56. - P. 739-746.

10. Zavgorodnij A.I. Dezinfikujuchij preparat dlja zahistu sil'gosptvarin vid tuberkul'ozu [Tekst] / A.I. Zavgorodnij, A.P. Palij // Agrarna nauka - virobnictvu. - K., 2014. - № 1 (67). - S. 20. 